\title{
An unexpectedly high prevalence of colonization with the intestinal spirochaete Brachyspira aalborgi amongst residents of the Indonesian island of Bali
}

\author{
Correspondence \\ David J. Hampson \\ d.hampson@murdoch.edu.au
}

Received 25 February 2008

Accepted 1 June 2008

\author{
M. Arif Munshi, K. Rini Margawani, lan D. Robertson and David J. Hampson \\ School of Veterinary and Biomedical Sciences, Murdoch University, Murdoch, WA 6150, Australia
}

\section{INTRODUCTION}

Brachyspira aalborgi and Brachyspira pilosicoli are anaerobic spirochaetes that colonize the human large intestine, where they attach by one cell end to the colorectal epithelium to form a characteristic 'false brush border' (Hovind-Hougen et al., 1982; Mikosza \& Hampson, 2001). The potential role of the two species as pathogens of humans has remained somewhat controversial, although it is thought that colonization with these spirochaetes can be associated with a variety of non-specific clinical problems, including chronic diarrhoea, abdominal discomfort and failure to thrive in children (Brooke et al., 2006; Körner \& Gebbers, 2003; Marthinsen et al., 2002; Weisheit et al., 2007). Besides humans, B. aalborgi has been detected in non-human primates (Duhamel et al., 1997; Munshi et al., 2003). In comparison, B. pilosicoli colonizes a variety of species of animals and birds, in which it is a recognized cause of mild colitis and diarrhoea (Hampson et al., 2006).

Many aspects of the epidemiology of these two spirochaete species remain unclear. B. aalborgi in particular has remained enigmatic, mainly because of its extremely slow growth rate and the fact that few isolates are available for study (Brooke et al., 2003; Calderaro et al., 2003; HovindHougen et al., 1982; Kraaz et al., 2000). To overcome difficulties with isolation, PCR assays have been developed for these two spirochaete species using DNA extracted from colorectal biopsies (Mikosza et al., 1999) or faeces

Abbreviations: $\mathrm{Cl}$, confidence interval; $\mathrm{OR}$, odds ratio.
(Mikosza et al., 2001). Based on differences in 16S rRNA gene sequences in DNA extracted from fixed biopsy tissues, at least three clusters or 'lineages' of B. aalborgi have been described (Jensen et al., 2004; Mikosza et al., 2004; Pettersson et al., 2000), but to date all isolates that have been cultured have belonged to cluster one. Using PCR-based methods, B. aalborgi has been detected at a consistent prevalence of around $6 \%$ in individuals from four different human population groups in Australia (Brooke et al., 2006), in villagers in Assam, India (Munshi et al., 2004), and in patients in northern Italy (Calderaro et al., 2007).

In a previous study, selective anaerobic culture was used to study the prevalence of $B$. pilosicoli in individuals from the island of Bali, Indonesia (Margawani et al., 2004). Prevalence rates of 3.3-23.4\% were found depending on location, with the higher values found being similar to those found for B. pilosicoli in rural Australian Aborigines (Lee \& Hampson, 1992) and in villagers in India (Munshi et al., 2004) and in Papua New Guinea (Trott et al., 1997).

The aim of this study was to examine the prevalence and potential risk factors for human colonization with $B$. aalborgi in Bali. The faecal samples used were a subset of those previously collected to determine the prevalence of $B$. pilosicoli by selective anaerobic culture and PCR, and the original questionnaire responses were also used to determine potential risk factors for colonization (Margawani et al., 2004). 


\section{METHODS}

Approval. This study was conducted with the approval of the Murdoch University Human Ethics Committee. The subjects involved gave their informed consent to participate in the study.

Source of faecal samples. Faecal samples were obtained from 469 people living in four traditional Balinese villages, one semi-urban location and Denpasar, the capital city. The numbers of people sampled from the six locations are shown in Table 1. Participants were sampled twice in one year (in August, the dry season, and December, the wet season), giving 938 samples in total. The four rural farming villages were well-run by the local communities, and there was a strong appreciation for the need to preserve a clean environment and safe water supply. The residents of urban Denpasar were generally settled, well-housed and had a reasonably high standard of living. In comparison, the peri-urban centre of Sesetan was crowded, had a large transient population and had a generally poor environment (Margawani et al., 2004). Samples were transported to the laboratory at $4{ }^{\circ} \mathrm{C}$ and maintained at this temperature until processed.

DNA extraction and PCR. The methodology used for DNA extraction and PCR analysis has been described previously (Munshi et al., 2004). Briefly, over a 1-month period, DNA was extracted from batches of stored faecal samples using a QIAamp DNA Stool Mini kit (Qiagen). The primers used were designed to amplify a 471 bp section of the 16S rRNA gene of B. aalborgi. In previous experiments, the authors showed that this PCR had a sensitivity of detection of between $2.5 \times 10^{4}$ and $2.5 \times 10^{5}$ cells of $B$. aalborgi $(\mathrm{g} \text { faeces) })^{-1}$ (Munshi et al., 2004).

DNA sequencing. Twenty-two randomly selected PCR products were sequenced with a commercially available cycle sequencing kit (ABI PRISM Dye Terminator Cycle Sequencing Ready Reaction kit; Applied Biosystems), according to the manufacturer's instructions. The sequence data obtained were aligned and compared with $16 \mathrm{~S}$ rRNA gene sequences of $B$. aalborgi type strain $513 \mathrm{~A}^{\mathrm{T}}$ (GenBank accession no. Z22781) and B. pilosicoli type strain $\mathrm{P} 43 / 6 / 78^{\mathrm{T}}$ (GenBank accession no. U23032) using SeqEd, version 1.0.3 (Applied Biosystems).

Statistical analysis. One-way analysis of variance was used for analysis of continuous data, whilst either a $\chi^{2}$ test for independence or Fisher's exact test was used for categorical data. Odds ratios (ORs) and $95 \%$ confidence intervals (CIs) were calculated. Comparisons were made with previous results for $B$. pilosicoli from the same samples (Margawani et al., 2004).

\section{RESULTS AND DISCUSSION}

The 22 PCR products that were sequenced had $98.6-100 \%$ nucleotide sequence identity with the product from $B$. aalborgi type strain $513 \mathrm{~A}^{\mathrm{T}}$, confirming the specificity of the PCR for B. aalborgi. The sequences were consistent with them coming from lineage one, although only a small region of the 16S rRNA gene was sequenced.

The number of samples that were positive for B. aalborgi using the PCR at the six locations at both sampling times is shown in Table 1. Overall, 118 (25.2\%) of the 469 August samples and $104(22.2 \%)$ samples from December were PCR-positive. The prevalence at different locations and times was highly variable, ranging from 15.6 to $41.5 \%$. Combining the results for the four traditional villages gave 85/378 (22.5\%) positive individuals in August and 74/378 $(19.6 \%)$ in December. For Sesetan (peri-urban), the corresponding figures were 41.5 and $38.5 \%$, respectively, and for Denpasar (the capital city) they were 23.1 and $19.2 \%$, respectively.

The relationship between location and colonization was significant $\left(P_{\mathrm{AUG}}=0.019\right.$ and $\left.P_{\mathrm{DEC}}=0.001\right)$. Living in Sesetan was an important risk factor (OR 2.4, CI 1.4-4.2 in August; and OR 2.6, CI 1.5-4.5 in December). Presumably in Sesetan there is an increased opportunity for $B$. aalborgi to be transmitted or to persist amongst people in the crowded and poorer environment. In our previous study, colonization rates for B. pilosicoli were also high at Sesetan (Margawani et al., 2004).

Although water source was not a significant risk factor for August $(P=0.148)$, it was for December $(P=0.029)$, with people drinking well water being more likely to be colonized than those drinking tap water (OR 1.6, CI 1.12.6). Conversely, a significant negative relationship existed for tap water (OR 0.6, CI 0.4-0.9), suggesting a protective effect. Water from wells is more likely to be contaminated from environmental sources, including human faeces, than tap water. The significant effect in the wet season (December) would be consistent with transmission associated with local flooding of septic tanks located near many

Table 1. Number of people positive for B. aalborgi amongst 469 individuals sampled twice in the same year at six locations in Bali August, dry season; December, wet season.

\begin{tabular}{|c|c|c|c|c|c|c|}
\hline Location & Description & $\begin{array}{l}\text { No. of people } \\
\text { sampled }\end{array}$ & $\begin{array}{l}\text { No. positive in } \\
\text { August (\%) }\end{array}$ & $\begin{array}{l}\text { No. positive in } \\
\text { December (\%) }\end{array}$ & $\begin{array}{c}\text { No. positive } \\
\text { at both samplings } \\
(\%)\end{array}$ & $\begin{array}{c}\text { No. newly } \\
\text { positive in } \\
\text { December (\%) }\end{array}$ \\
\hline Karang Suwung & Village & 94 & $27(28.7)$ & $25(26.6)$ & $14(14.9)$ & $11(11.7)$ \\
\hline Payangan Desa & Village & 89 & $17(19.1)$ & $18(20.2)$ & $9(10.1)$ & $9(10.1)$ \\
\hline Badung & Village & 73 & $15(20.5)$ & $12(16.4)$ & $12(16.4)$ & 0 \\
\hline Denpasar & Urban & 26 & $6(23.1)$ & $5(19.2)$ & $4(15.4)$ & $1(3.8)$ \\
\hline Total & & 469 & $118(25.2)$ & $104(22.2)$ & $75(16.0)$ & $29(6.2)$ \\
\hline
\end{tabular}


of the wells, particularly in Sesetan. Despite this possibility, the overall prevalence did not show a consistent seasonal difference. Furthermore, colonization with B. pilosicoli was more common in people who used well water in August but not in December (Margawani et al., 2004). The reason for these apparent differences in seasonally associated risks of water supply for the two spirochaete species is unclear, but presumably reflects some differences in the biology of the spirochaetes.

The previously described prevalence for $B$. pilosicoli in the same individuals who were sampled here was $9.8 \%(46 / 469)$ in August and $11.9 \%$ (56/469) in December (Margawani et al., 2004). By comparing these previous data on $B$. pilosicoli with the current data, a total of $27 / 469(5.8 \%)$ and $24 / 469(5.1 \%)$ individuals were identified as being colonized with both spirochaete species at the two sampling times. On both occasions, infection with one spirochaete was a significant risk factor for colonization with the other $(P=0.000$ and 0.000 , respectively). Similar associations between these two spirochaete species have been recorded elsewhere (Brooke et al., 2006; Munshi et al., 2004) and suggest the existence of some common risk factors or predisposition for colonization by the two species.

There was no significant association of age, gender, occupation, animal contact, faecal consistency or health status with colonization by $B$. aalborgi. The lack of association with the presence of clinical symptoms is at odds with results from Australia, where colonization with B. aalborgi amongst Aboriginal patients was associated with chronic diarrhoea, failure to thrive and being underweight (Brooke et al., 2006). Such differences could perhaps be associated with the presence of different 'lineages' or strains of B. aalborgi in the different countries, but this possibility was not investigated.

The same PCR methodology was used in this study as in our other studies, and consequently these results can be compared. Previously, prevalence rates for $B$. alborgi of $\sim 6 \%$ were found amongst four different population groups in Australia (Brooke et al., 2006) and in villagers in Assam, India (Munshi et al., 2004). Consequently, the prevalence for $B$. aalborgi in Bali at all locations was unexpectedly high. Furthermore, the prevalence of $B$. aalborgi in Bali was greater than the prevalence of $B$. pilosicoli, and again this was the reverse of previous findings in other countries where comparable surveys have been conducted using faeces from unselected individuals from the local populations (Brooke et al., 2006; Munshi et al., 2004). The reasons for the differences in prevalence rates in Bali are not immediately obvious, but presumably are a result of specific local conditions. These could include factors associated with ethnicity, the local diet and the colonic microbiota, or differences in other aspects of the biology of the spirochaete strains that were detected.

Of the 118 individuals who were PCR-positive for B. aalborgi at the first sampling, $75(63.3 \%)$ were also positive at the second sampling 4 months later. These individuals may have been reinfected during this interval and/or they may have been persistently infected. As only 29 individuals $(6.2 \%$ of the total population) were newly positive in December, the mean duration of colonization would need to have been at least 3 months to maintain the overall high prevalence rates at the different locations (15.6-41.5\%; mean positivity $22.6 \%)$. Furthermore, the disparity at Sesetan between the number of new infections in December $(7.7 \%)$ and the high prevalence $(\sim 40 \%)$ would suggest that colonization was more prolonged at this location and/or that this large subset of individuals was being regularly reinfected. Again, these possibilities are likely to be due to factors associated with the poor socio-economic environment in Sesetan.

Further work is required to determine why the apparent prevalence of $B$. aalborgi is so high in Bali compared with the situation in other communities. In particular, it would be useful to apply molecular typing methods to help determine the duration of infection with specific strains and to obtain full 16S rRNA gene sequences to determine whether the 'lineages' or strains of $B$. aalborgi that are distributed in Bali are different from those present in other countries and regions.

\section{REFERENCES}

Brooke, C. J., Riley, T. V. \& Hampson, D. J. (2003). Evaluation of selective media for isolation of Brachyspira aalborgi from human faeces. J Med Microbiol 52, 509-513.

Brooke, C. J., Riley, T. V. \& Hampson, D. J. (2006). Comparison of prevalence and risk factors for faecal carriage of the intestinal spirochaetes Brachyspira aalborgi and Brachyspira pilosicoli in four Australian populations. Epidemiol Infect 134, 627-634.

Calderaro, A., Villanacci, V., Conter, M., Ragni, P., Piccolo, G., Zuelli, C., Bommezzadri, S., Guégan, R., Zambelli, C. \& other authors (2003). Rapid identification of Brachyspira aalborgi from rectal biopsies and faeces of a patient. Res Microbiol 154, 145-153.

Calderaro, A., Gorrini, C., Peruzzi, S., Piccolo, G., Dettori, G. \& Chezzi, C. (2007). Occurrence of human intestinal spirochetosis in comparison with infections by other enteropathogenic agents in an area of the Northern Italy. Diagn Microbiol Infect Dis 59, 157-163.

Duhamel, G. E., Elder, R. O., Muniappa, N., Mathiesen, M. R., Wong, V. J. \& Tarara, R. P. (1997). Colonic spirochetal infections in nonhuman primates that were associated with Brachyspira aalborgi, Serpulina pilosicoli, and unclassified flagellated bacteria. Clin Infect Dis 25, S186-S188.

Hampson, D. J., Oxberry, S. L. \& La, T. (2006). Potential for zoonotic transmission of Brachyspira pilosicoli. Emerg Infect Dis 12, 869-870.

Hovind-Hougen, K., Birch-Andersen, A., Henrik-Nielsen, R., Orholm, M., Pedersen, J. O., Teglbjærg, P. S. \& Thaysen, E. H. (1982). Intestinal spirochaetosis: morphological characterization and cultivation of the spirochete Brachyspira aalborgi gen. nov., sp. nov. J Clin Microbiol 16, 1127-1136.

Jensen, T. K., Teglbjaerg, P. S., Lindboe, C. F. \& Boye, M. (2004). Demonstration of Brachyspira aalborgi lineages 2 and 3 in human colonic biopsies with intestinal spirochaetosis by specific fluorescent in situ hybridization. J Med Microbiol 53, 341-343.

Körner, M. \& Gebbers, J. O. (2003). Clinical significance of human intestinal spirochetosis - a morphologic approach. Infection 31, 341-349. 
Kraaz, W., Pettersson, B., Thunberg, U., Engstrand, L. \& Fellström, C. (2000). Brachyspira aalborgi infection diagnosed by culture and $16 \mathrm{~S}$ ribosomal DNA sequencing using human colonic biopsy specimens. J Clin Microbiol 38, 3555-3560.

Lee, J. I. \& Hampson, D. J. (1992). Intestinal spirochaetes colonizing Aborigines from communities in the remote north of Western Australia. Epidemiol Infect 109, 133-141.

Margawani, K. R., Robertson, I. D., Brooke, C. J. \& Hampson, D. J. (2004). Prevalence, risk factors and molecular epidemiology of Brachyspira pilosicoli in humans on the island of Bali, Indonesia. J Med Microbiol 53, 325-332.

Marthinsen, L., Willén, R., Carlén, B., Lindberg, E. \& Värendh, G. (2002). Intestinal spirochetosis in eight pediatric patients from Southern Sweden. APMIS 110, 571-579.

Mikosza, A. S. J. \& Hampson, D. J. (2001). Human intestinal spirochetosis: Brachyspira aalborgi and/or Brachyspira pilosicoli? Anim Health Res Rev 2, 101-110.

Mikosza, A. S. J., La, T., Brooke, C. J., Lindboe, C. F., Ward, P. B., Heine, R. G., Guccion, J. G., de Boer, W. B. \& Hampson, D. J. (1999). Polymerase chain reaction amplification from fixed tissue indicates the frequent involvement of Brachyspira aalborgi in human intestinal spirochetosis. J Clin Microbiol 37, 2093-2098.

Mikosza, A. S. J., La, T., Margawani, K. R., Brooke, C. J. \& Hampson, D. J. (2001). PCR detection of Brachyspira aalborgi and Brachyspira pilosicoli in human faeces. FEMS Microbiol Lett 197, 167-170.
Mikosza, A. S. J., Munshi, M. A. \& Hampson, D. J. (2004). Analysis of genetic variation in Brachyspira aalborgi and related spirochaetes determined by partial sequencing of the $16 \mathrm{~S}$ rRNA and NADH oxidase genes. J Med Microbiol 53, 333-339.

Munshi, M. A., Taylor, N. M., Mikosza, A. S. J., Spencer, P. B. S. \& Hampson, D. J. (2003). Detection by PCR and isolation assays of the anaerobic intestinal spirochete Brachyspira aalborgi from the feces of captive nonhuman primates. J Clin Microbiol 41, 1187-1191.

Munshi, M. A., Traub, R. J., Robertson, I. D., Mikosza, A. S. J. \& Hampson, D. J. (2004). Colonization and risk factors for Brachyspira aalborgi and Brachyspira pilosicoli in humans and dogs on tea-estates in Assam, India. Epidemiol Infect 132, 137-144.

Pettersson, B., Wang, M., Fellström, C., Uhlén, M., Molin, G., Jeppsson, B. \& Ahrné, S. (2000). Phylogenetic evidence for novel and genetically different intestinal spirochetes resembling Brachyspira aalborgi in the mucosa of the human colon as revealed by $16 \mathrm{~S}$ rDNA analysis. Syst Appl Microbiol 23, 355-363.

Trott, D. J., Combs, B. G., Oxberry, S. L., Mikosza, A. S. J., Robertson, I. D., Passey, M., Taime, J., Sehuko, R. \& Hampson, D. J. (1997). The prevalence of Serpulina pilosicoli in humans and domestic animals in the Eastern Highlands of Papua New Guinea. Epidemiol Infect 119, 369-379.

Weisheit, B., Bethke, B. \& Stolte, M. (2007). Human intestinal spirochetosis: analysis of the symptoms of 209 patients. Scand J Gastroenterol 42, 1422-1427. 